\title{
$\$$
}

\section{Hoitajien työajan merkitys asiakkaiden elämänlaadulle vanhusten ympärivuorokautisessa hoidossa}

\author{
Riitta Räsänen
}

\begin{abstract}
Hoitajien toiminta on vanhusten hoivatyössä tärkeää asiakkaan kokemalle elämänlaadulle. Koska hoitajan antaman ajan pituus ei ratkaise vaan sen sisältö (Räsänen 2011), tarkastelen hoitajien työajan kohdentumisen merkitystä asiakkaiden kokemaan elämänlaatuun. Tulosten mukaan hoitajien asiakkaalle antama aika on huventunut muuhun kuin suoraan asiakkaan hyvinvoinnin tukemiseen. Silti se oli kokonaisuutena tärkeää asiakkaan elämänlaadulle, vaikkakin toistuvien, eriytyneiden ja sairauspainotteisten rutiinitehtävien ohella paneutuminen hoitotyössä erityisesti elämänlaadun kannalta tärkeisiin asioihin oli niukkaa. Taustalla voi olla hoitohenkilöstön asenteeseen, määrään ja kustannuksiin liittyviä tekijöitä. Aihetta ei ole aiemmin tutkittu vanhuspalveluissa, vaikka palvelujärjestelmän odotetaankin vastaavan ikääntyneiden asiakkaiden hyvän elämänlaadun tuottamisesta. Organisaatio rakentuu tehtäväänsä suorittavista yksilöistä ja asiakkaan hyvää elämänlaatua voidaan pitää myös työntekijän näkökulmasta tavoiteltavana tuloksena omasta työstä. Tutkimus tehtiin neljän keskisuomalaisen kunnan kuudessa vanhusten ympärivuorokautisen hoidon organisaatiossa vuonna 2013. Hoitoyksiköistä löytyi eroja käytännön hoito- ja palvelutyön kohdentumisessa antaen viitteitä asiakkaan elämänlaadulle tärkeistä ammattityön menetelmistä ja niiden vaikutuksesta resurssien kohdentamiseen.
\end{abstract}

\section{Johdanto}

Työajaksi luetaan työhön käytetty aika sekä aika, jonka työntekijä on velvollinen olemaan työpaikalla työnantajan käytettävissä. Vanhustyön hoitohenkilöstön työajan käyttöä on tutkittu tieteellisesti vähän. Enimmäkseen niissä on selvitetty henkilöstötarpeita $(\mathrm{mm}$. Kane ym. 2001; Hegney ym. 2003; Morin \& Leblanc 2005; Arling ym. 2007; Sharkey ym. 2011; Vento 2014). Suomessa vanhus- ten laitoshoidosta tehdyissä tutkimuksissa on tarkasteltu asiakas- ja tuottavuusnäkökulmaa (esim. Vento 2014) tai etsitty tunnuslukuja henkilöstöresurssien määrittämiseen (esim. Rauhala 2008). Henkilöstön ja asiakkaiden määrän keskinäistä suhdetta kuvaava tunnusluku ei välttämättä huomioi asiakkaiden yksilöllistä hoidon tarvetta eikä hoitotyöntekijöiltä vaadittavaa osaamista (Ruontimo 2012, 37), mutta se ohjaa resurssien jakoa. Sen suhteuttamista työn määrään pidetään yleisesti hyvä- 
nä (Fahey \& Burbridge 2008) unohtamatta kuitenkaan osaamisen, toiminnan organisoinnin ja johtamisen merkitystä (Spilsbury ym. 2011; Räsänen 2011; Räsänen \& Leppälehto 2016). Henkilöstömäärän kalibrointi optimaaliselle tasolle on vaikeaa (Buchan 2005). Henkilöstövoimavarojen tutkimusmittareina on käytetty hoitotyön sekä hoitoisuuden, hoitopäivien ja -jaksojen seurantaa sekä hoitotyön voimavaroja ja tulosta. Toimintakykyarviointia ei näihin tutkimuksiin ole juurikaan liitetty, vaikka resurssien oikeanlainen kohdentaminen asiakkaiden hoitoisuuden perusteella parantaa tasapainoa hoidon tarpeen ja hoitotyön resurssien välillä (Fagerström 2009). Henkilöstö kokee vaikeana vähentää työaikaa juuri vanhuksilta (Morin ja Leblanc 2005, 214-220).

Työturvallisuuslaki (738/2012) korostaa ennakoivaa suunnittelua, mutta sairaanhoitajien työolotutkimus (Partanen ym. 2005, 26) osoitti, että sairaanhoitajien työaika suuntautuu huonosti asiakkaan todellisiin hoidollisiin tai hoitoa edistäviin tehtäviin. Vähäinen tukipalveluhenkilöstön määrä onkin muokannut hoitohenkilöstön työnkuvia ammatillista itsetuntoa heikentäviksi (Pusa 2007, 32) aiheuttaen kielteisiä tunnekokemuksia (Hegney ym. 2003). Liukkosen $(2008,172)$ mielestä nykyisellä miehityksellä on vaikea saada hyviä tuloksia. Kane ym. (2001) havaitsivat pitkäaikaishoidon hoitohenkilöstön suorittavan viidesosan työajastaan samanaikaisia toimintoja, mikä vaikeuttaa työajan todellisen jakautumisen arviointia.

Resurssien määrää ei pidetä hoivatyössä ratkaisevana vaan aikaansaannoksia (Laine 2005, 81-82; Räsänen 2011, 157-168). Resurssien tarkoituksenmukainen kohdentaminen on osa hoidon ja johtamisen laatua, jolla puolestaan on yhteys myös asiakkaan kokemaan elämänlaatuun (Tervo-Heikkinen 2008, 60; Pieper, Heislbetz \& Frommelt 2008, 255-280; Räsänen 2011, 180-181). Työntekijän asenne ja välittäminen ovat keskeisiä märiteltäessä palvelua (Räsänen 2011, 125; Stenvall \& Virtanen 2012, 51-65). Hoivalla tavoitellaan asiakkaan hyvää elämänlaatua, jolloin aineellisten resurssien lisäksi merkittäviä ovat myös ei-aineelliset resurssit, kuten asenne ja motivaatio (esim. Räsänen 2011).

Vaikka elämänlaadun yhtenevä teoreettinen määritelmä puuttuu, on olemassa yhteisymmärrys siitä, mitä elämänlaatu on. Tutkimusasetelmissa koetun elämänlaadun käsite saa samoja piirteitä kuin hyvinvoinnin käsite, mutta siitä huolimatta ne ovat käsitteinä erillisiä (esim. Vaarama \& Ollila 2008, 118). Koettu elämänlaatu on moniulotteinen ja dynaaminen prosessi, jossa yksilölliset, yhteisölliset, yhteiskunnalliset ja kulttuuriset tekijät ovat vuorovaikutuksessa keskenään. Muutos yhdellä ulottuvuudella voi merkitä muutosta myös muilla ulottuvuuksilla. (Vaarama ym. 2008.) Vaikka oikeus hyvään elämänlaatuun ei riipu yksilön iästä tai kunnosta, eliniän pidentymisen johdosta vanhuus on osalle vanhuksista hyvä elämänvaihe, osalle enimmäkseen kielteinen (Koskinen \& Seppänen 2013, 447).

Gerontologisissa elämänlaadun tutkimuksissa käytetään Powell M. Lawtonin (1991) mallia hyvästä elämästä, joka koostuu fyysisestä hyvinvoinnista, käyttäytymisen kompetenssista, fyysisestä elinympäristöstä ja koetusta elämänlaadusta. Ympäristön ja yksilön välinen yhteensopivuus ovat tärkeitä (personenvironment-fit), eli mitä enemmän ihmisellä on avun arvetta, sitä paremmin ympäristön tulisi häntä tukea.WHO:n (1988) mär̈ittelyn mukaan elämänlaatu on yksilöllinen kokemus, johon vaikuttaa se kulttuuri,jossa ihminen elää. Elämänlaadun ulottuvuudet ovat: fyysinen terveys ja toimintakyky, mukaan lukien kognitio, psyykkinen hyvinvointi, sosiaalinen hyvinvointi ja elinympäristö, johon WHO lukee myös aineelliset elinolot ja tarvittavien palvelujen saatavuuden. Elämänlaadun teorioissa näyttää tavalla tai toisella toistuvan Lawtonin ajattelu (Vaarama ym. 2008).

WHO jakaa elämänlaadun neljään ulottuvuuteen, joita ovat fyysinen, psyykkinen, sosiaalinen ja elinympäristö (WHO 1998; ks. myös Lawton 1991; Vaarama \& Pieper 2008). 
Toisten apua tarvitsevien iäkkäiden elämänlaatua muovaavat suuresti myös hoivapalvelut, jolloin voidaan puhua hoivasta riippuvaisesta elämänlaadusta (care-related quality of life). Siinä tavoitteena on iäkkään hyvän elämänlaadun tukeminen, jolloin toimintojen tulee suuntautua iäkkäiden toimintakyvyn ja autonomian tukemiseen, hänen yksilöllisten tarpeidensa tyydyttämiseen, sekä hyvään vuorovaikutukseen asiakkaan kanssa. Tätä tukevat hoivatyön selkeä missio, hyvä johtaminen ja työn organisointi sekä työyhteisöjen hyvinvoinnin tuki. (Vaarama ym. 2008.)

Hyvää elämänlaatua ikääntyneenä vahvistavat yksilöllisten tarpeiden tyydyttyminen, itselle riittävä terveys ja toimintakyky, positiivinen kuva omasta itsestä, onnellisuus, jäljellä olevan toimintakyvyn ja terveyden kokeminen itselleen hyvänä ja riittävänä, hyvä mielenterveys ja hengellinen tasapaino, itseä tyydyttävät ihmissuhteet ja asuinolot sekä oman elämän rajallisuuden hyväksyminen (Vaarama ym. 2008; Vaarama ym. 2010, 133). Elämänlaadun ja mielenvireyden kannalta positiivisuutta luovat vaikuttamisen mahdollisuus ja osallistuminen erilaisiin harrastuksiin (Sainio, Koskinen, Sihvonen, Martelin \& Aromaa 2014, 3839). Yli 80-vuotiaat arvostavat psyykkisen ja sosiaalisen hyvinvoinnin tekijöitä ja terveyttä. Tärkeää on saada tarvittaessa apua ja tulla kohdelluksi yhteiskunnassa ja palvelujärjestelmässä hyvin. Perhe, ystävät ja läheiset ovat tärkeitä. (Vaarama \& Ylönen 2006; Vaarama ym. 2010; Vaarama ym. 2014.) Näistä lähtökohdista rakentuu myös hyvän hoivan periaatteet (Vaarama \& Ylönen 2006; Räsänen 2011). Jollekin hyvän elämänlaadun tekijä voikin olla toiselle huono, eikä ulkopuolinen koskaan voi tavoittaa yksilön kokemusmaailmaa (Vaarama ym. 2008; Räsänen 2011). Elämänlaatu on sitä tasapainoisempi tila, mitä paremmin yksilön tarpeisiin vastataan hänelle sopivilla menetelmillä (Cummins 2005).

Tutkimuksissa on havaittu hoivan tärkeys vanhusten kokemalle elämänlaadulle sen eri ulottuvuuksilla (Vaarama ym. 2008; Vaarama ym. 2010; Räsänen 2011). Tulokset korostavat toimintakyvyn ja ihmissuhteiden merkitystä mutta myös palvelujen vaikuttavuutta. Palvelujen hyvä kohdentuminen on määrää tärkeämpi. (Laine 2005, 81-82; TervoHeikkinen 2008, 60; Räsänen 2011, 125-126, 157-169,180-181.) Ympärivuorokautisen hoivan asiakkaiden elämänlaatu on tutkimuksissa todettu kohtuulliseksi (Vaarama ym. 2008; Räsänen 2011). Pitkäaikaistutkimusten mukaan elämänlaadun hyvyys ja taso vaihtelevat. Valtaosalla pitkäaikaishoivan asiakkaista on elämänlaatua usein heikentävä muistisairaus.

\section{Aineisto ja menetelmät}

Työajanseurantakaavake laadittiin yhteistyössä vanhuspalvelujen hoitajien kanssa luokittelemalla hoiva- ja hoitotyö palvelujen suhteen välittömään ja välilliseen hoitotyöhön, työyksikkökohtaisiin toimintoihin ja henkilökohtaiseen ajankäyttöön alakohtineen. Palveluasumisen ja laitoshoidon työajanseurantatietojen vertailua helpottaa hoitotyön ja menetelmien samankaltaisuus. Tuloksissa huomioidaan palveluasumisen hoitohenkilökunnan kodinhoidolliset tehtävät.

Elämänlaatuarvioinnissa käytettiin Care Keys -mittaristoa, jonka teoreettinen viitekehys pohjaa hyvinvoinnin tuotantoteoriaan (The Production of Welfare), jossa hoitotyö nähdään elämänlaatua välittäväksi tekijäksi ja hyvinvointi lopputuotteena (Vaarama ym. 2008, 5-6). Asiakkaan kognitio arvioitiin MMSE-mittarilla ja tuloksen perusteella tehtiin haastattelu tai havainnointi. Mittarin korkein pistemäärä on 30, normaalin ja lievästi heikentyneen raja on 24/30 (Hänninen \& Pulliainen 2001, 348-357.) Muut mittarit olivat: 1 . CLINT-IC-Bref, strukturoitu haastattelulomake ympärivuorokautisen hoivan asiakkaille. Kokonaispistemäärä on 80 pistettä, suurempi arvo osoittaa parempaa elämänlaatua. 
2. QUALID, havainnointimittari keskivaikeaa ja vaikeaa dementiaa sairastaville. Mitä alhaisempi pistemäärä on, sitä parempi on elämänlaatu, kokonaispistemäärä 11-55 pistettä. (Weiner ym. 2000, 114-116.) 3. CORNELL (Cornell Scale for Depression in Dementia, CSDD), ikääntyneiden muistisairaiden depressio-oireiden tunnistaminen ja vaikeusaste, kokonaispistemäärä $0-38$ pistettä. Yhteispistemärää $>10$ viittaa mahdolliseen vakavaan masennukseen, yhteispistemäärä $>18$ vakavaan masennukseen ja yhteispistemäärä $<6$ vakavien depressio-oireiden puuttumiseen. (Alexopoulos ym. 1988.)

\section{Kuvaus tutkimukseen osallistuneista}

Tutkimusaineisto koottiin vuonna 2013 neljässä Keski-Suomen kunnassa, joiden väestömäärä on 152000 asukasta. Osallistuneet kunnat ja hoitoyksiköt osallistuivat myös vuonna 2011 elämänlaatututkimukseeni Jyvässeudulla ( $\mathrm{N}=682)$. Tällöin tutkimukseen osallistuneista henkilöistä $63 \%$ asui laitoksessa, mutta tässä tutkimuksessa vain $30 \%$. Perusjoukoksi muodostui 345 vanhusta, joista tavoitteena oli saada tutkimukseen $30 \%$. Lopulta osallistujia oli $25 \%(\mathrm{~N}=89)$. Palveluasumisessa asui 229 vanhusta, joista 45 oli haastatteluun kykenevää. Heidät kaikki valittiin mukaan, mutta muutama vanhus menehtyi ennen aineistonkeruuta tai kieltäytyi haastattelusta, joten haastateltavia jäi 39. Laitoshoidossa oli 116 asiakasta, joista tutkimukseen osallistui 50 asiakasta. Otanta havainnointitutkimukseen tehtiin poimimal1a heistä aakkosjärjestyksessä joka kolmas. Muutama omainen ei antanut lupaa havainnoida. Kunnallisen ja yksityisen palveluntuottajien toimintaosuudet ympärivuorokautisen hoivan tuottajina olivat jokseenkin yhtä suuret. Kaksi sosiaalialan opiskelijaa toteuttivat haastattelut. Yhteen haastatteluun kului aikaa 2560 minuuttia. Haastattelun teossa huomioitiin luottamuksellisuus, vastaamisen vapaaehtoisuus ja riittävän ajan antaminen vastaamiseen.
Vanhuspalveluorganisaatiot (6) koostuivat useista pienemmistä hoivayksiköistä, joiden asiakasmäärä vaihteli palveluasumisen 12 asiakkaan pienkodista lähes 50 asiakkaan vanhainkotiosastoon. Henkilöstömitoituksen suhdeluvut olivat kansallisten suositusten rajoissa vaihdellen $0,55-0,68$ välillä. Hoidettavien määrä yksiköissä oli vakaa, eikä vaihtuvuutta juurikaan ollut.

Hoivayksiköiden toimintaperiaatteissa, toimintakulttuurissa ja arvoissa korostuivat asukkaiden toimintakyvyn ylläpitäminen, voimavaralähtöisyys ja mahdollisimman hyvä elämänlaatu, joita toteutti myös tukipalveluhenkilöstö (laitoshuoltaja, kuntohoitaja, viriketoiminnanohjaaja). Omahoitajuus oli toimintatapana kaikissa hoivapaikoissa, mutta käytännön toteutuksissa oli runsaasti eroja. Yksiköissä oli vapaa vierailuaika ja läheisten mahdollisuutta osallistua hoitoon korostettiin.

Työajanseuranta tehtiin kahden viikon aikana kulloinkin paikalla olevalle henkilöstölle. Jokainen työntekijä seurasi työaikaansa strukturoidulla seurantakaavakkeella viiden peräkkäisen työvuoron ajan 15 minuutin tarkkuudella. Mukana oli 131 työntekijää tehden 614 työvuoroa aamu- tai iltatyössä. Työajat määräytyivät työn tarpeesta, ajoittumisesta ja työn intensiteetistä. Esimiehet eivät osallistuneet seurantaan.

\section{Tulokset}

Ei-muistisairaiden asiakkaiden kokema elämänlaatu

Kaikki haastateltavat vanhukset asuivat palvelutaloissa (vrt. Räsänen 2011). Tutkimukseen osallistuneiden palvelutalojen 229 vanhuksesta vain 45 kykeni haastatteluun MMSE-arvon perusteella. Heistä 39 (43\%) osallistui haastatteluun. Haastateltavien keski-ikä oli 85,6 vuotta. Aiemmassa tutkimuksessani se oli 83 vuotta vastaten silloista pitkäaikaishoivan asiakkaiden keski-ikää Suomessa. Vastaajista 74 \% oli nai- 
sia ja $26 \%$ miehiä. Jakauma noudattaa aiempia tutkimuksia. Suurimmalla osalla koulutustaso oli alempi perusaste (myös Räsänen 2011). Taustatietoina kysyttiin elämänlaadun kokemiseen mahdollisesti vaikuttavia traumaattisia kokemuksia kahden viimeisen vuoden aikana. Vähän alle puolet oli itse sairastunut vakavasti, reilusti yli puolella läheinen perheenjäsen oli sairastunut vakavasti, ja kolmasosalla oli ollut taloudellisia vaikeuksia.

Elämänlaadun kokonaisuutta kuvaavien pisteiden keskiarvo oli 56,6 pistettä, keskihajonta 7,0 pistettä ja vaihteluväli 41-72 pistettä. Elämänlaatua voi pitää kohtalaisena. Räsäsen tutkimuksessa koetun elämänlaadun summapisteiden keskiarvo oli 58,3 pistettä ja keskihajonta 6,78. Vanhainkotien elämänlaatuarvioinnin keskiarvo oli tuolloin 56,9 pistettä, kunnallisessa palveluasumisessa 59,6 ja yksityisessä palveluasumisessa 58,0. Lähes kaikissa yksiköissä keskiarvo on edelliskertaan nähden hieman alempi. Koetun elämänlaadun arvioinnissa elämänlaatu-ulottuvuuksien painoarvot ovat kokonaisuutena varsin lähellä toisiaan.

Elämänlaadun fyysistä ulottuvuutta kuvataan tyytyväisyydellä terveyteen ja toimintakykyyn. Noin kolmasosa haastatelluista oli tyytyväisiä terveyteensä, erittäin tyytymättömiä oli kymmenesosa. Melkein puolet oli tyytyväisiä päivittäisistä toimista selviytymiseen. Vaaraman ym. (2014) mukaan valtaosa 80 vuotta täyttäneistä kokeekin elämänlaatunsa hyväksi, mutta osalla fyysisen toimintakyvyn heikkeneminen ja taloudellisen tilanteen vaikeudet heikentävät elämänlaatua. Viidesosalla heistä on paljon ongelmia; huono toimintakyky, yksinäisyys, kivut, taloudellinen ahdinko ja riittämätön avun saanti kasautuvatkin samoille ihmisille. Aiemmassa tutkimuksessani terveyteensä ja omaan toimintakykyyn tyytyväisiä oli hieman enemmän. Oman aktuaalin terveystilan ja sairauden kanssa elämään oppiminen ja sopeutuminen parantavat psyykkistä ja sosiaalista elämänlaatua, mutta onko iäkkäiden ihmisten vaatimustaso oman terveyden suh- teen nousemassa? Onko heikentyneeseen terveyteen sopeutuminen aiempaa vaikeampaa?

Sosiaalinen ulottuvuus sai yhtenevät tulokset aiempaan tutkimukseeni nähden. Kolme neljäsosaa oli tyytyväisiä ihmissuhteisiinsa. Yksinäisyyttä koki kuitenkin joka kymmenes. Sosiaalinen aktiivisuus tai ihmisten läheisyys ei siis välttämättä poista yksinäisyyden tunteita. Myös Vaarama ym. (2014) havaitsivat, että 80 vuotta täyttäneistä suomalaisista yksinäisyyttä koki 30-50 \% ikäryhmästä riippuen ja syvää yksinäisyyttä 10-18\%. Yksinäisimpiä olivat yli 85-vuotiaat ja erityisesti miehet. Sosiaalinen hyvinvointi säilyi etenkin naisilla.

Elämänlaadun psyykkinen ulottuvuus kuvaa asiakkaan kokemaa psyykkistä hyvinvointia. Puolet vastaajista oli kohtuullisen tyytyväisiä itseensä, nauttivat elämästä ja kokivat onnellisuutta. Tyytymättömyyttä oli aiempaan tutkimukseeni verrattuna enemmän. Elämänlaadun ympäristöulottuvuuden arviointi osoittaa palveluolosuhteiden sopivan tällaiseen asumiseen ja elämään. Reilu puolet vastanneista koki, että heillä oli kohtuullisesti mahdollisuuksia arjen toimintaan, joka kymmenes ei. Vanhukset kaipaavat mielekästä tekemistä, elämää, jotain mitä odottaa ja mikä katkaisee tapahtumattomuutta. Myös turvallisuuden kokeminen on yksi ikääntyneiden perustarpeista (ETENE 2008). Palveluasumisessa lähes puolet tunsi olonsa jollain tavalla turvattomaksi, joka kymmenes jopa erittäin turvattomaksi. He olivat tyytymättömiä myös terveyteensä ja itseensä sekä heillä oli paljon lääkehoitoa. He eivät juurikaan nauttineet elämästään eikä heillä ollut tarmoa arkipäivän elämiseen. Muutama heistä mainitsi sivumennen syyksi elämisen asunnossaan yksin. Kolmasosa vastanneista koki, että heillä on täysin riittävästi rahaa tarpeisiinsa nähden. Huolestuttavaa on, että joka viides vanhus kertoi, etteivät rahat riitä elämiseen.

Mahdollisuuksiaan saada terveyspalveluita peräti $30 \%$ piti riittämättömänä. Tulos häm- 
Taulukko 1. Elämänlaadun ulottuvuuksien pistemäärät.

\begin{tabular}{|l|c|c|c|}
\hline $\begin{array}{l}\text { Elämänlaadun } \\
\text { ulottuvuus }\end{array}$ & $\begin{array}{c}\text { Ulottuvuuden } \\
\text { pistemäärän keskiarvo }\end{array}$ & $\begin{array}{c}\text { Räsäsen } \\
\text { tutkimus (2011) }\end{array}$ & $\begin{array}{c}\text { Korkein mahdollinen } \\
\text { pistemäärä }\end{array}$ \\
\hline Fyysinen & 12,7 & 9,9 & $/ 20,0$ \\
Psyykkinen & 17,0 & 24,8 & 125,0 \\
Sosiaalinen & 11,1 & 7,7 & $/ 15,0$ \\
Ympäristö & 14,0 & 15,7 & $/ 20,0$ \\
Elämänlaadun & 56,6 & 58,3 & $/ 80,0$ \\
kokonaispisteet & $(\mathrm{n}=44)$ & $(\mathrm{n}=288)$ & \\
\hline
\end{tabular}

mästyttää, sillä ovathan he siirtyneet palveluasumiseen juuri heikentyneen terveydentilansa ja toimintakykynsä takia. Huono terveydenhoito haavoittaa eniten juuri huonosta terveydestä kärsiviä hauraita vanhuksia (Fahey ym. 2003). Palveluasumisen lääkärityö oli hyvin hajanaista, jatkuvuudeltaan heikkoa ja rajoittui parhaimmillaankin vain arjen virka-aikaan. Lääkärityön järjestäminen vaihteli sen mukaan, mikä on palveluasumista tuottava toimijataho. Palveluasumisessa sairaanhoitajien määrä oli perinteistä laitoshoitoa niukempi. Kokonaisuutena tämän osion tulokset olivat varsin yhdensuuntaisia aikaisemman tutkimukseni kanssa (Taulukko 1).

\section{Asiakkaiden arvio hoidon laadusta}

Asiakkailta kysyttiin 11 muuttujan avulla kokemuksia hoidon laadusta ruokailuun, hygieniaan ja hoitajien toimintaan liittyen. Tavoitteena oli selvittää, miten hoiva ja hoito toimivat asiakkaalle elämänlaadun tekijöinä, sillä mitä enemmän elämänpiiri kapeutuu, sitä merkittävämpää on hoiva elämänlaatua tukevana ja ylläpitävänä keinona (Vaarama 2002, 11-18). Asiakkaiden hyvinvointi toteutui tarpeiden tyydyttämisen kannalta, kun sitä vertaa Cumminsin (2005) käsitykseen elämänlaadusta, jota hän pitää tasapainoisena tilana vasta, kun yksilön tarpeet otetaan huomioon ja niihin vastataan hänelle parhaiten sopivilla menetelmillä.
Kokonaisuutena hoidon laatu koettiin varsin hyvänä (Taulukko 2). Mitä pienempi on pistemäärä, sen parempi on hoidon koettu laatu. Alin mahdollinen pistemäärä on $11 \mathrm{ja}$ ylin 56 pistettä. Kaksi yksityistä hoitopaikkaa on yhdistetty tuloksissa, koska toisessa oli vain muutama haastatteluun kykenevä asiakas. Nämä yksiköt pärjäsivät laadun osalta tässä tutkimuksessa parhaiten. Kokonaisuutena hoidon laatu arvioitiin kauttaaltaan aiempaan tutkimukseeni verrattuna hieman heikommaksi mutta silti varsin hyväksi. Vastaajista $66 \%$ oli tyytyväisiä hoitopaikkaansa, edelliskerralla peräti $88 \%$.

Laitoshoito sai aiemmassa tutkimuksessani kauttaaltaan varsin hyvät hoidon laatuarvioinnit, mutta tässä tutkimuksessa ei laitoshoidossa ollut yhtään haastatteluun kykenevää asiakasta. Tämä kertoo, että hoito ja huolenpito toteutuvat pitkäaikaisena laitoshoitona jo varsin hyvin vanhuspalvelulain (2013) mukaisesti eli vain tiukoin lääketieteellisin tai asiakas- ja potilasturvallisuuteen liittyvin perustein. Palveluasumisen kyky tuottaa laadultaan hyvää hoitoa verrattuna laitoshoitoon ei ole tulosten mukaan itsestäänselvyys. Toisaalta vanhukset ovat entistä huonokuntoisempia myös palveluasumisessa, mikä voi vääjäämättä vaikuttaa myös kokemuksiin. Hoiva on ikääntyneelle tärkeä päivittäinen tekijä,joten myös kokemus sen laadusta on tärkeä hänen elämänlaadulleen (Vaarama \& Pieper 2008, 72). 
Taulukko 2. Hoidon laatu kunnittain.

\begin{tabular}{|l|c|c|}
\hline Yksikkö & n & $\begin{array}{c}\text { Hoidon laatupisteet } \\
\text { yhteensä }\end{array}$ \\
\hline Palveluasuminen kunta 1 & 5 & 23 \\
\hline Palveluasuminen kunta 2 & 8 & 21,9 \\
\hline Palveluasuminen kunta 3 & 10 & 20,1 \\
\hline Palveluasuminen kunta 4 & 6 & 19,8 \\
\hline $\begin{array}{l}\text { Yksityinen palveluasuminen } \\
\text { kunta 4 }\end{array}$ & 10 & $\mathbf{1 6 , 4}$ \\
\hline Kaikki yhteensä & 39 & $\mathbf{2 1 , 4}$ \\
\hline
\end{tabular}

Hoitajat ovat asiakkaan elämänlaadun tukijoita

Hoitajien toiminnan merkitystä selvittävät kysymykset käsittelen kokonaisuutena ja haen yhtymäkohtia asiakkaiden kokemaan elämänlaatuun. Aikaisemmassa tutkimuksessani asiakkaan tyytyväisyys hoitajiin näkyi parempana elämänlaatuna. Tulos vahvistui myös tässä tutkimuksessa: mitä tyytyväisempi vanhus oli kokonaisuutena hoitajan toimintaan, sitä parempana hän koki oman elämänlaatunsa. Hoitajat koettiin enimmäkseen varsin ymmärtäväisinä, kuuntelevina, ystävällisinä sekä vanhuksia varsin hyvin arvostavina. Soraääniä tuli kuitenkin joka viidenneltä haastatellulta vanhukselta.

Yleensä ottaen asiakkaat olivat jokseenkin tyytyväisiä hoitoonsa, hoidon laatuun ja hoitajien toimintaan. Hajontaa tuli eniten kysyttäessä hoitajien ajan riittävyydestä. Vain $27 \%$ koki, että hoitajien antama aika oli pääasiassa riittävää, edellisessä tutkimuksessani 57 \%. Ajan riittävyys on myös kokemuksellista: jos hoitaja ei pysähdy ja kohtaa asiakasta aidosti, voi asiakkaalle jäädä tunne, ettei hän saanutkaan hoitajalta aikaa. Hoitajien antama emotionaalinen ja henkinen tuki kuuluvat asiakkaan elämänlaadun psyykkiseen ulottuvuuteen. Hoitoalalla hoitajien työtehtävät ja niihin kohdistuvat paineet tuntuvat olevan samanlaisia riippumatta siitä, minkälainen on järjestelmän rakenne (Räsänen \& Leppälehto 2016).

Hoitajan ja vanhuksen keskinäinen vuorovaikutus ja toiminta ovat laatutekijöitä ja vanhuksen kokemaa tärkeä ihmissuhdetta pidetään jopa terveyden, toimintakyvyn ja elämänlaadun perustana. Niinpä hoitajien toiminnan merkityksen tarkastelua jatkettiin vertaamalla vielä asiakkaan elämänlaadun summapistemäärää hoitajien toiminnasta muodostuneeseen summapistemäärään käyttämällä Pearsonin ja Spearmanin korrelaatiota (Taulukko 3). Tulos oli selkeä: mitä suurempi oli hoitajien arvion pistemäärä, sitä matalampi oli QoL-pistemäärä. Hoitajan toiminta on siis merkittävä, sillä mitä paremmaksi asiakas arvioi hoitajien toiminnan, sitä parempi oli hänen elämänlaatunsa.

Taulukko 3. Hoitajien merkitys asiakkaiden elämänlaadulle.

\begin{tabular}{|l|c|c|c|}
\hline Menetelmä & korrelaatio & $\mathbf{p}$ & adjustoitu selitysaste \\
\hline Pearson & -0.4897515 & 0.001553 & 0.2193 \\
\hline Spearman & -0.5172414 & 0.0007467 & 0.2477 \\
\hline
\end{tabular}




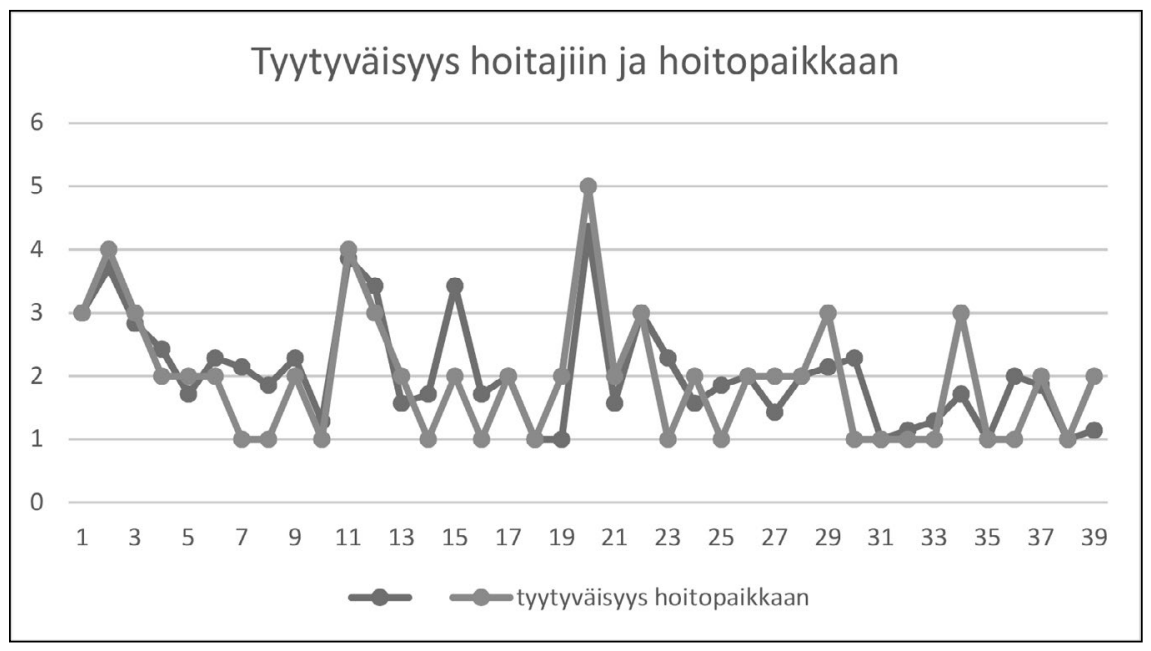

Kuvio 2. Tyytyväisyys hoitajien toimintaan ja hoitopaikkaan.

Tyytyväisyys hoitajien toimintaan näkyi myös parempana tyytyväisyytenä koko hoitopaikkaan (Kuvio 2). Vastausvaihtoehdot ovat: 1=Kyllä aina / 2=Kyllä yleensä / 3=Joskus / 4=Harvoin / 5=Ei koskaan.

Yhteenvetona voi siis sanoa, että hoitajien toiminnan laadulla on suuri merkitys asiakkaan kokemaan elämänlaatuun. Ei siis ole yhdentekevää, miten ja mihin hoitajan työaikaa kohdennetaan.

\section{Muistisairaiden asiakkaiden elämänlaatu}

Qualid-elämänlaatuhavainnointi tehtiin kaikille alle 18 MMSE-pistettä saaneille. Kymmenellä henkilöllä sairaus oli vielä keskivaikeassa vaiheessa (MMSE 12-20/30) ja lopuilla sairaus vaikeassa (MMSE alle 12) vaiheessa (Hänninen \& Pulliainen 2001, 348-357). Keskiarvo havainnointitutkimuk- seen osallistuneilla oli 6,85 MMSE-pistettä (Taulukko 4).

Observoinnin suoritti vanhuksen omassa asuinympäristössä hänet hyvin tuntenut hoitaja, mieluiten omahoitaja yhden viikon mittaisena ajanjaksona. Observointiin osallistui 50 vanhusta. Taulukosta 5 näkyy elämänlaatu- ja masennustestin pisteiden jakautuminen sekä MMSE-pisteet, jotka olivat laitoshoidossa kaikista alhaisimmat. Kaikkien tutkittavien muistisairaiden Qualid-pisteiden keskiarvo oli 21,25 ja keskihajonta 2,6. Elämänlaatu oli siis varsin hyvällä tasolla. Muistisairaiden asiakkaiden elämänlaatu ei eronnut laitoshoidon ja palveluasumisen välillä. Kokonaisuutena tulos on hieman parempi kuin edelliskerralla (Qualidpisteiden keskiarvo 23,9 ja keskihajonta 5,9) tai Helsingin vastaavassa tutkimuksessa (Soini ym. 2008), jossa se oli 22,4 pistettä.

Taulukko 4. Tutkimukseen osallistuneiden muistisairaiden MMSE-pisteet.

\begin{tabular}{|lcccccccccccccccccccc|}
\hline MMSE & 0 & 1 & 2 & 3 & 4 & 5 & 6 & 7 & 8 & 9 & 10 & 11 & 12 & 13 & 14 & 15 & 16 & 17 & 18 & $\mathrm{~N}$ \\
\hline $\mathrm{f}$ & 17 & 0 & 2 & 3 & 3 & 1 & 0 & 0 & 0 & 1 & 6 & 2 & 3 & 3 & 2 & 2 & 1 & 0 & 4 & 50 \\
\hline
\end{tabular}


Taulukko 5. Qualid- ja Cornell-testiin osallistuneiden MMSE-arvojen keskiarvo ja tulosten keskiarvo hoitomuodoittain

\begin{tabular}{|l|c|c|c|c|}
\hline Hoitomuoto & N & MMSE & Qualid & Cornell \\
\hline laitoshoito & 24 & 3,25 & 21,9 & 6,7 \\
\hline palveluasuminen & 26 & 9,8 & 21,9 & 2,3 \\
\hline
\end{tabular}

Muistisairaiden ihmisten elämänlaatuun vaikuttivat epämiellyttävä olotila, elämänilojen rajallisuus, surullisuus ja kivut (myös Räsänen 2011,131).Viidesosa vanhuksista koki ajoittain ikäviä tuntemuksia ja alakuloa, oleminen vaikutti muutoinkin ongelmalliselta. Mielihyvän kokemuksia ja elämän iloakin löytyi: vanhuksista $75 \%$ hymyili spontaanisti ainakin kerran päivässä ja vaikutti tyytyväisiltä oloonsa.

Masennustestissä kaikkien havainnoitujen Cornell-pisteiden keskiarvo oli 4,6. Alexopouloksen (1988) mukaan Cornellmittarin yhteispistemäärä <6 viittaa vakavien depressio-oireiden puuttumiseen. Vain kahdeksalla vanhuksella viidestäkymmenestä Cornell-pisteiden kokonaismäärä oli 6 tai yli, yhdellä heistä arvo oli 10. Edelliskerralla tutkimuksessa $(2011,132)$ masentuneisuutta oli reilulla neljäsosalla havainnoiduista. Tulos on siten tältä osalta parempi.

\section{Hoitohenkilökunnan työajan seurannan tulokset}

Työajan pää- ja alakohdat on luokiteltu taulukkoon 6. Alakohtien luokittelu on varsin tarkkaa. Työajan seurantakaavakkeessa oli näille vielä tarkennetut sisältökuvaukset.

\section{Välitön hoitotyö}

Välitön hoitotyö on suoraan asiakkaalle tehtävällä työllä annettua aikaa. Sairaanhoitajat työskentelivät yksiköissä keskimäärin yhtä pitkiä aamutyövuoroja arkisin ja viikonloppuisin. Keskimääräinen työaika työvuorossa oli sairaanhoitajilla 8 tuntia ja lähihoitajilla 7,75 tuntia. Lähihoitajat työskentelivät keskimäärin 7,5 tuntia aamuvuoroissa ja 8 tuntia iltavuoroissa sekä arkena että viikonloppuisin. Yövuorot olivat 10 tuntia. Työaikajoustoja ei ollut: vain yhdessä yksikössä lähihoitaja työskenteli osittain sekä aamu- että iltavuorossa (välivuoro).

Sairaanhoitajilla välittömän hoitotyön toteuttaminen vei työajasta 37-51 \% (Taulukko 7). Yksittäisiä poikkeuksia ylöspäin oli vain,jos sairaanhoitajia oli työvuorossa enemmän kuin yksi. Lähihoitajien välitön hoitotyö oli kaikissa yksiköissä aamuvuorossa noin puolet työajasta ja iltavuorossa lähes 70 \%. Peltokorven (2007) työajan seurantatutkimuksissa välittömän työajan osuus vanhusten pitkäaikaisessa laitoshoidossa oli 55,7 \% kokonaistyöajasta kaikissa ammattiryhmissä pois lukien lähiesimiehet. Taulukkoon 7 on poimittu perushoito ja ohjaus - osiosta erikseen asiakkaan toimintakykyä edistävä työaika. Sairaanhoitajat on yhdistetty samaan sarakkeeseen anonymiteetin säilymiseksi.

Palveluasumisessa sairaanhoitajien määrä oli vähäinen, joten asiakkaiden voinnin pääasiallinen seurantavastuu näytti olevan lähihoitajilla, toisin kuin laitoshoidossa, jossa sairaanhoitajia oli noin puolet enemmän. Sairaanhoidollisten tehtävien osuus oli laitoshoidossa lähihoitajilla varsin vähäistä.

Omaistyön tuloksissa syntyi arkikokemusten ja tulosten välistä ristiriitaa. Hoitajien arkipalautteissa omaisyhteistyö vie paljon aikaa (Räsänen 2014), mutta tulokset kertovat toista: kokonaistyöajasta alle kaksi prosenttia eli työvuorossa vain 6-7 minuuttia. Tulos voi kertoa asenteesta omaistyötä kohtaan. Omaistyö koetaan psyykkisesti kuormittavaksi, jopa epämiellyttäväksi, joten siihen kuluva aika voi tuntua todellisuudesta poiketen pitemmältä. Kyse voi olla myös työtehtävien keskinäisestä arvojärjes- 
Taulukko 6. Työajan seurannassa käytetyt päätoiminnot ja niiden jakautuminen tarkennettuihin alakohtiin.

\begin{tabular}{|c|c|c|c|}
\hline 1. Välitön hoitotyö & 2. Välillinen hoitotyö & 3. Yksikkökohtainen työ & $\begin{array}{l}\text { 4. Työntekijän } \\
\text { henkilökohtainen aika }\end{array}$ \\
\hline 1.1 Perushoito ja ohjaus & $\begin{array}{l}2.1 \text { Hoitotyön } \\
\text { kirjaaminen (myös } \\
\text { arviointi-mittarit) }\end{array}$ & $\begin{array}{l}\text { 3.1 Kodinhoidolliset työt } \\
\text { ja siivoaminen }\end{array}$ & $\begin{array}{l}\text { 4.1 Henkilökohtaiset } \\
\text { asiat, } \\
\text { tauot (ruoka-ja } \\
\text { kahvitauko) }\end{array}$ \\
\hline 1.1.1 Hygienia & $\begin{array}{l}2.2 \text { Hoitotyön } \\
\text { suullinen viestintä }\end{array}$ & $\begin{array}{l}3.2 \text { Ateriahuolto } \\
\text { (ruoan haku, jakaminen) }\end{array}$ & $\begin{array}{l}4.2 \text { Muu } \\
\text { (toiminnot ilman } \\
\text { ryhmää) }\end{array}$ \\
\hline $\begin{array}{l}\text { 1.1.2 WC-käynnissä } \\
\text { avustaminen }\end{array}$ & $\begin{array}{l}\text { 2.3 Asiakastyön } \\
\text { kommunikaatio, } \\
\text { lääkärin konsultointi }\end{array}$ & $\begin{array}{l}\text { 3.3 Pyykki- ja } \\
\text { vaatehuolto } \\
\text { (vuodevaatteiden vaihto) }\end{array}$ & \\
\hline 1.1.3 Asentohoito & $\begin{array}{l}\text { 2.4 Lääkehoito, } \\
\text { apteekkiasiat }\end{array}$ & 3.4 Toimistotyö & \\
\hline $\begin{array}{l}\text { 1.1.4 Ruokailu } \\
\text { (syöttäminen) }\end{array}$ & $\begin{array}{l}2.5 \text { Kuljetus, odottelu, } \\
\text { näytteiden vienti }\end{array}$ & $\begin{array}{l}\text { 3.5 Kommunikaatio } \\
\text { (työkeskustelut) }\end{array}$ & \\
\hline $\begin{array}{l}\text { 1.1.5 Lääkkeet } \\
\text { (lääkkeiden antaminen) }\end{array}$ & & $\begin{array}{l}\text { 3.6 Kokoukset ja } \\
\text { koulutukset/tiedonvaihto, } \\
\text { työkaverin ohjaus }\end{array}$ & \\
\hline $\begin{array}{l}\text { 1.1.6 Muu (mm. } \\
\text { vainajanlaitto) }\end{array}$ & & 3.7 Opiskelijaohjaus & \\
\hline $\begin{array}{l}\text { 1.2 Sairaanhoito } \\
\text { (haavahoito, injektiot, } \\
\text { näytteet) }\end{array}$ & & $\begin{array}{l}\text { 3.8 Välineet, kalibrointi, } \\
\text { varastojen tarkastus/ } \\
\text { täydennys }\end{array}$ & \\
\hline \multicolumn{4}{|l|}{ 1.3 Aktivointi, apuvälinet } \\
\hline \multicolumn{4}{|l|}{$\begin{array}{l}\text { 1.4 Voinnin tarkkailu ja } \\
\text { oireiden seuranta }\end{array}$} \\
\hline \multicolumn{4}{|l|}{1.5 Omaisyhteistyö } \\
\hline \multicolumn{4}{|l|}{ 1.6 Siirrot, kuljetukset } \\
\hline 1.7 Tulo- ja lähtötilanne & & & \\
\hline
\end{tabular}

tyksestä. Omaistyötä tehdään usein muun tehtävän ohessa, esimerkiksi samalla, kun avustetaan vanhusta, jolloin avustaminen katsotaankin ensisijaiseksi. Sairaanhoitajien vastuulla oli lähihoitajiin verrattuna hieman enemmän omaisyhteistyötä.

Hyvän elämänlaadun kannalta tärkeä toimintakyvyn edistäminen ja arkivirikkeiden aika jäi niukaksi. Palveluasumisen ja laitoshoidon välillä ei ollut eroja, mutta yksiköiden välillä oli pieniä eroja. Ulkoilu oli olematonta kaikissa yksiköissä. Syynä lienee talviaika tai asenne. Virikkeellistä toimintaa oli kokonaisuutena vähän, vaikka Nussbaumin (2011) mukaan ihminen tarvitsee naurua, leikkiä ja virkistäytymistä. Hoidon tarkoituksena on tukea vanhuksen omaa toimijuutta. Toimijuus ei katoa, vaikka heikentynyt toimintakyky ohjaakin ympärivuorokautiseen hoitoon (Pirhonen \& Pietilä 2015). 
Taulukko 7. Hoitohenkilöstön välittömään hoitotyöhön käyttämä työaika kokonaistyöajasta ( $N=131)$.

\begin{tabular}{|l|c|c|c|}
\hline $\begin{array}{l}\text { VÄLITÖN HOITOTYÖ: } \\
\text { toimintoalue }\end{array}$ & $\begin{array}{c}\text { Lähihoitajat } \\
\text { palveluasuminen \% } \\
(\mathbf{f = 5 6 )}\end{array}$ & $\begin{array}{c}\text { Lähihoitajat } \\
\text { pitkäaikaishoito } \% \\
(\mathbf{f = 5 1 )}\end{array}$ & $\begin{array}{c}\text { Sairaanhoitajat \% } \\
(\mathbf{f = 2 4})\end{array}$ \\
\hline 1. Perushoito ja ohjaus \\
(1.1. Toimintakyvyn edistäminen & $\begin{array}{c}31,7 \\
(6,6)\end{array}$ & $\begin{array}{c}48,5 \\
(5,3)\end{array}$ & $\begin{array}{c}30,5 \\
(2,5)\end{array}$ \\
\hline 2. Sairaanhoito & 2,8 & 0,7 & 5,1 \\
\hline 3. Aktiviteetit ja viriketoiminta & 3,0 & 1,0 & 4,8 \\
\hline 4. Voinnin tarkkailu & 4,0 & 2,5 & 1,4 \\
\hline 5. Yhteistyö omaisten kanssa & 1,2 & 1,7 & 2,0 \\
\hline 6. Siirtäminen ja kuljettaminen & 1,6 & 1,3 & 1,0 \\
\hline 7. Tulo ja lähtötilanne & 1,3 & 0 & 1,0 \\
\hline Yhteensä \% työajasta & 45,6 & 58,7 & 45,8 \\
\hline
\end{tabular}

\section{Välillinen hoitotyö}

Välillisen hoitotyön osuus vaihteli sairaanhoitajilla runsaasti (13-22\%), lähihoitajilla se oli tasaisempaa (12-17\%). Eniten työaikaa vei hoitotyöhön liittyvä viestintä (6\%, vaihteluväli 2,8-14,7 \%). Rauhalan ja Fagerströmin (2007) tutkimuksessa välillisen hoitotyön osuus kasvoi mitä enemmän hoitotyöntekijöillä oli koulutusta. Myös tässä tutkimuksessa sairaanhoitajilla meni kokonaisuutena hieman lähihoitajia enemmän aikaa esimerkiksi kirjaamiseen. Suurin kirjaamiseen käytetty työaika sairaanhoitajilla kului yksityisessä palveluasumisessa, jossa pääkirjaamisvastuu oli sälytetty juuri heille. Kirjaamisen laatuvaatimukset esittää palvelun ostaja. Kirjaamisaika oli miltei kolminkertainen $(14,7 \%)$ verrattuna kunnalliseen palveluasumiseen (5\%) ja laitoshoitoon (6\%). Lähihoitajilla kirjaaminen oli yksityisessä palveluasumisessa samansuuntainen kuin kunnallisella puolella. Hoidon ja palvelujen dokumentointi on olennainen osa hoitoa niin palveluasumisessa kuin laitoshoidossakin. Monet lait, asetukset ja ohjeet määrittävät kirjaamisen suuntaviivat, mutta johto vastaa sen laadusta, koska kirjaaminen on asiakasturvallisuuden ja laadukkaan hoitotyön pohja (Saranto 2008).
Kirjaamiseen käytetty työaika näkyy taulukossa 8, jossa sairaanhoitajat on yhdistetty samaan sarakkeeseen anonymiteetin säilymiseksi. Kirjaamiseen käytetyn ajan lisääntyminen pitäisi näkyä suullisen raportoinnin vähenemisenä, mikä ei täysin käytännössä toteudu.

Yksityisessä palveluasumisessa myös asukaskohtainen viestintä kulutti paljon sairaanhoitajan työaikaa. Tiedonkulkuun käytetty aika onkin kaksijakoinen: asiakkaan saamaa hoitoa ja palveluja koskevien tietojen kirjaaminen tietojärjestelmiin sekä työntekijöiden välinen päivittäinen tiedonkulku, joka koskee esimerkiksi asiakkaita, työnjakoa, työvuorosuunnittelua ja poissaoloja.

\section{Yksikkökohtainen työ}

Yksikkökohtaiseen työhön käytetty aika oli varsin suuri vaihdellen 9-34 prosentin välillä. Eniten työaikaa kuluttivat 1 . kodinhoidolliset tehtävät (astianpesukoneen tyhjennys ja täyttö, siivoustehtävät), 2. ruokahuolto (ruoan haku, tarjolle laittaminen) ja 3. palaverit ja koulutukset. Yhteisöllisyyden, konsensuksen ja tiedon jakaminen vaati sairaanhoitajilla 5,3 \% työajasta, lähihoitajilla palveluasumisessa $2,9 \%$ ja laitoshoidossa 1,3\%. Toimistotyötehtävien osuus 
Taulukko 8. Hoitohenkilöstön välilliseen hoitotyöhön käyttämä työaika.

\begin{tabular}{|l|c|c|c|}
\hline $\begin{array}{l}\text { VÄLILLINEN HOITOTYÖ } \\
\text { toimintoalue }\end{array}$ & $\begin{array}{c}\text { Lähihoitajat } \\
\text { palveluasuminen } \\
\mathbf{\%}(\mathbf{n = 5 6 )}\end{array}$ & $\begin{array}{c}\text { Lähihoitajat } \\
\text { pitkäaikaishoito \% } \\
(\mathbf{n = 5 1 )}\end{array}$ & $\begin{array}{c}\text { Sairaanhoitajat \% } \\
(\mathbf{n = 2 4 )}\end{array}$ \\
\hline Hoitotyön kirjaaminen & $\mathbf{4 , 4}$ & $6, \mathbf{1}$ & $\mathbf{8 , 2}$ \\
\hline Hoitotyön raportointi & 5,2 & 5,6 & 5,0 \\
\hline Asiakastyöhön liittyvä kommunikointi & $\mathbf{2 , 5}$ & 0,5 & 4,8 \\
\hline Lääkehoito & 3,8 & $\mathbf{2 , 1}$ & 5,6 \\
\hline Kuljetus, odottelu, etsiminen & $\mathbf{0 , 7}$ & $\mathbf{0 , 2}$ & $\mathbf{2 , 0}$ \\
\hline \multicolumn{1}{|c|}{ Yhteensä \% työajasta } & $\mathbf{1 6 , 6}$ & $\mathbf{1 4 , 5}$ & $\mathbf{2 5 , 6}$ \\
\hline
\end{tabular}

Taulukko 9. Hoitohenkilöstön henkilökohtaisen ajan osuus (\%) kokonaistyöajasta.

\begin{tabular}{|l|c|c|}
\hline $\begin{array}{l}\text { Lähihoitajat palveluasuminen } \\
\text { \% }(\mathbf{n = 5 6 )}\end{array}$ & $\begin{array}{c}\text { Lähihoitajat pitkäaikaishoito } \\
\mathbf{\%}(\mathbf{n}=\mathbf{5 1})\end{array}$ & $\begin{array}{c}\text { Kaikki sairaanhoitajat } \\
\mathbf{\%}(\mathbf{n = 2 4})\end{array}$ \\
\hline 6,2 & 8,6 & 8,0 \\
\hline
\end{tabular}

oli alle 4 prosenttia. Tukipalvelutehtävien määrä on suuri mutta vastaa muita kansallisia tuloksia.

\section{Työntekijän henkilökohtainen aika}

Työntekijöillä on lakisääteinen oikeus lepohetkeen. Vanhustyössä joutuisa ateriointi työpaikalla on työaikaa, kun työvuoron pituus on yksityissektorilla vähintään kuusi ja kuntapuolella viisi tuntia. Ruokailuun käytettävä aika on 1520 minuuttia. Lakisääteinen taukoaika on kahdeksan tunnin työvuorossa 30 minuuttia. Tässä tutkimuksessa oma aika vaihteli 15 minuutista jopa 105 minuuttiin yhtä 5-9 tunnin pituista työvuoroa kohden. Suhteutettuna työaikaan vaihteluväli oli 5-15 prosenttia. Iltavuoroissa ja viikonloppuvuoroissa henkilökohtainen aika oli arkiaamuja hieman suurempi nousten jopa 15 prosenttiin työajasta. Taulukossa 9 sairaanhoitajat on yhdistetty samaan sarakkeeseen anonymiteetin säilymiseksi.

Henkilöstömitoituksella ei ollut merkitystä taukoajan pituuteen. Lepotauot olivat pisimpiä perinteisessä laitoshoidossa, vaikka kodinhoidollisia ja asiakasta aktivoivia tehtäviä oli siellä vähän. Palveluasumisessa kunnallinen ja yksityinen sektori eivät juurikaan eronneet toisistaan.

Työajan kohdentuminen asiakkaiden elämänlaadun hyväksi

Ei-muistisairaiden asiakkaiden elämänlaatu oli parempi, jos välittömän hoitotyön osuus oli vähintään $50 \%$ työajasta ja muistisairailla vähintään $60 \%$. Asiakkaalle annettavaa aikaa nakersivat yksikkökohtaiset tehtävät, jotka söivät työaikaa 9-34 \%. Samoin hoitajan oma henkilökohtainen aika suhteutettuna työaikaan vaihteli 5-15 \% työajasta. Tämä aika on selvästi suurempi kuin esimerkiksi asiakkaan toimintakyvyn edistämiseen tai virkistämiseen käytetty aika. Jäikö asiakkaan kokema elämänlaatu sen vuoksi alhaiseksi? Aiheuttaako se asiakkailla turvattomuuden ja yksinäisyyden kokemuksia? Olisiko vanhusten elämänlaatu parempi, jos hoitajat olisivat heidän kanssaan enemmän? Vanhukset ilmaisivat kuitenkin, ettei annetun ajan pituus sinällään ollut ratkaisevaa vaan sen sisältö. Hoidon laatu koettiin hyvänä mutta elämänlaatu sen sijaan vain kohtalaise- 
na. Sosiaalinen vuorovaikutus ja virikkeellinen toiminta jäivät niukaksi, vaikka niillä on todettu positiivisia vaikutuksia ihmisten fyysiseen ja henkiseen hyvinvointiin ja siten parempaan elämänlaatuun. Pelkkä perushoito ei siis riitä varmistamaan hyvää elämänlaatua asiakkaille.

\section{Pohdinta}

Tutkimuksessa tehtiin henkilöstölle työajanseuranta ja tuloksia tarkasteltiin suhteessa toiminnan lopputuloksiin eli asiakkaan kokemukseen elämänlaadustaan. Tutkimusaineiston pienuudesta johtuen pääpaino oli merkitsevyyksien testaamisen sijaan enemmänkin käytännön erojen löytämisessä. Elämänlaadun tutkimusmenetelminä haastattelu tai havainnointi tehtiin asiakkaan kognition mukaan eettisesti tarkasti. Sekä haastattelujen että havainnointien tekijät koulutettiin tehtävään huolella. Työajanseurantamenetelmä sopi niin laitoshoitoon kuin palveluasumiseen, sillä niissä työajan kuvaaminen ja raportointi tapahtuvat samoin periaattein. Tietojen vertaileminen oli haasteellista. Palveluasuminen on avohoitoa, vaikka muistuttaakin käytännössä laitostyöskentelyä, mutta hoitohenkilökunnalla on usein myös kodinhoidollisia tehtäviä eikä avustavaa henkilökuntaa juurikaan ole.

Erot ammattiryhmien välillä näkyivät työajan kohdentumisessa: välillisen hoitotyön osuus kasvoi mitä enemmän hoitotyöntekijällä oli koulutusta. Hoitajien toiminta oli keskeistä ei-muistisairaan asiakkaan elämänlaadulle, vaikka asiakkaat pitivätkin hoitajien antamaa aikaa riittämättömänä. Tällöin aito läsnäolo voi jäädä vähäiseksi ja myös vanhuksen pyytämät asiat toteuttamatta (Sand 2008, 135-136). Ei-muistisairaista asiakkaista puolet koki heikentynyttä psyykkistä hyvinvointia. Kokevatko he heikkoa arvostusta, omaa elämää koskevan päätöksenteon ja valintojen puuttumista ja siten heikentynyttä elämänlaatua? Joka kymmenes koki yksinäisyyttä. Elämää rikastuttavaa ja tapahtumattomuutta katkaisevaa toimintaa oli vähän. Muistisairaiden ihmisten elämänlaatua heikensivät monet eri tekijät, mutta mielihyvän kokemuksiakin löytyi. Masentuneisuutta oli vain vähän.

Hoitajien työhön on sujahtanut enenevästi kodinhoitotehtäviä tukipalveluhenkilöstön vähyyden vuoksi. Käytäntö kuvaa pikemminkin osaamisen väärinkäyttöä kuin joustavuutta. Myös esimerkiksi Duffieldin ym. (2008) tutkimus osoitti, että hoitohenkilökunta tekee usein työtä, jota voisi tehdä vähemmän koulutettu henkilökunta. Välittömän hoitotyön määrää säätää asiakkaiden hoitoisuus mutta myös organisaation omat toimintamallit. Yksiköiden käytänteistä löytyi epäeettisiä piirteitä hoitajien ylipitkinä taukoina ja vanhusten aktivoinnin ja viriketyön vähyytenä, jopa puuttumisena. Tutkimuksissa on aiemminkin todettu, että välittömään hoitotyöhön ei aina käytetä aikaa, vaikka siihen olisi ollut mahdollisuus (Hentinen ym.1984, 19-84). Henkilökunta viestii työssään kiireen ja riittämättömyyden kokemuksia ja haluaisi antaa enemmän aikaa asiakkaille (Räsänen 2015). Jos hoitajien ylipitkiä taukoja tarkastellaan velvollisuuseettisestä näkökulmasta, taukojen pituus on normin vastainen. Työntekijän henkilökohtainen aika kulutti enemmän työaikaa kuin esimerkiksi asukkaan toimintakyvyn edistäminen tai sinänsä tarpeellinen viestintä.

Eniten kirjaamiseen käyttivät aikaa yksityisen palveluasumisen sairaanhoitajat: aika oli reilusti kaksinkertainen verrattuna kunnalliseen palveluasumiseen ja laitoshoitoon. Syynä voivat olla sairaanhoitajan toimenkuva tai palvelun ostajan vaatimukset tiedon koostamiseen, joka saattoi vaatia enemmän aikaa kuin tiedon hyödyntäminen. Ongelma on myös se, että yksityisessä palveluasumisessa hoitajilla ei ole oikeutta päästä palveluistaan itse maksavien asiakkaiden terveydenhuollon asiakirjoihin, vaan he joutuvat pyytämään tarvitsemiaan tietoja lääkäriltä.

Kaikki hoitotyötä kuormittavat tehtävät eivät tule hoitotyöstä vaan myös "varmuuden vuoksi" tehtävästä työstä. Tuloksista löytyy viit- 
teitä heikosta työn ja toiminnan suunnittelusta. Näin myös lääkäripalvelujen osalta, sillä peräti $30 \%$ piti riittämättömänä mahdollisuuksiaan saada terveyspalveluita. Tulos kertoo hajanaisesta, jatkuvuudeltaan heikosta ja rajoitetusta lääkärin työajasta, jolloin sen tavoitteena ei suinkaan ole iäkkään asiakkaan elämänlaadun tai hoitotyönkään menestyksellinen tukeminen.

\section{Johtopäätökset}

Tutkimuksessa löytyi tekijöitä, jotka edistävät ikääntyneen asiakkaan elämänlaadun varmistamista. Keskiöön nousivat hoitajien toiminta ja asiakkaalle annetun ajan sisältö. Tämä on signaali kehittää sekä palvelumuotoilua että henkilöstön asenne-, kohtaamis- ja vuorovaikutustaitoja entistä enemmän yhdessä asiakkaan kanssa tehtävän työn suuntaan. Asiakaslähtöinen toiminta ei salli asiakkaan huonoa kohtelua, epäeettisiä hoivaratkaisuja, asiakkaan omien voimavarojen aliarviointia eikä hänen osallisuutensa väheksymistä. Tulos puoltaa hoitajamitoituksen pitämistä riittävänä, mutta painottaa työajan kohdentamisen tärkeyttä. Myös lääkärityön toimivuutta ja vaikuttavuutta tulisi tarkastella huolella. Vanhoilla ihmisillä on oikeus hyvään lääketieteelliseen palveluun.

Tulokset vahvistavat aikaisempaa käsitystä siitä, että pelkkä hyvä hoidon laatu ei riitä takaamaan hyvää elämää niin ei-muistisairaille kuin muistisairaillekaan asiakkaille (Räsänen 2011). Laadukas toiminta on tavoitteellista, hyvin suunniteltua ja toteutettua myös henkilöstön työajan hyödyntämisen osalta eikä eettisiä ylilyöntejä tapahdu. Tulosten mukaan erilaiset velvollisuudet ja normit saattavat olla ristiriidassa keskenään.

Johtamisessa tarvitaan tietoa arjen perustyön toteutumisesta ja sen vaikuttavuudesta, jotta toiminnan ohjaaminen ja laadun kehittäminen mahdollistuvat. Tietoa työajan kulumisesta ja kohdentumisesta tarvitaan arvioitaessa asiakkaan kokemusten merkitystä, hen- kilöstöryhmien välistä tehtäväjakoa ja tarkoituksenmukaisuutta tai suunniteltaessa prosessien uudistamista. Tarve on ilmeinen, mikäli halutaan parantaa työn vaikuttavuutta, tehokkuutta, tuottavuutta tai laatua (esim. Arling \& Williams 2003). Vanhustyössä tärkein prosessi on asiakkaan koko elämä, joten perustehtäväsarjojen suorittamista helpottaa, kun tiedetään keskimääräinen niihin kuluva aika sekä mikä työnkulkua estää. Organisaatiossa ei aina olla riittävästi selvillä työntekijöiden arjen todellisista tekemisistä. Syinä voivat olla organisaatiorakenteeseen ja -kulttuurin sisältyvät tekijät, todellisen arjen ja strategioiden erillisyys sekä johtamisen rakenteet ja johtamisen heikko ymmärrys arkitodellisuuden vaatimuksista. Tulokset osoittavat, että sairaanhoidollinen osaaminen on tarpeen asiakkaiden huonokuntoisuuden vuoksi, mutta tarvitaan myös aikaa itse asiakkaalle, tekemistä yhdessä hänen kanssaan, sosiaalista, kodinhoidollista ja asiakkaiden asioiden hoitamiseen liittyvää osaamista ja työaikaa niihin.

Tulosten perusteella keskeiseksi tavoitteeksi vanhusten ympärivuorokautisessa hoivatyössä nouseekin asiakkaalle suoraan annettavan työajan osuuden kasvattaminen, sen suuntaaminen paremmin asiakkaalle sekä sen sisällön kehittäminen. Työajan ja osaamisen tarkoituksenmukainen kohdentaminen asiakkaille edistää heidän saamansa todellisen hyödyn lisäksi myös hoitajan ammatillisuuden parempaa toteutumista. Tavoite on konkreettisesti mahdollinen, kun työn ja johtamisen päämääräksi otetaan asiakkaan parempi elämänlaatu. Se saavutetaan, kun laajennetaan kapeutunutta ammattirakennetta, hyödynnetään nykyistä paremmin luovia ja aidosti asiakaslähtöisiä menetelmiä sekä laaja-alaisempaa ja ennakkoluulottomampaa yhteistyötä ja teknologisia ratkaisuja. On arvioitu, että robotiikkaa ja automatiikkaa hyödyntämällä voitaisiin vähentää ainakin 20 \% välilliseen hoitotyöhön kuluvaa aikaa vanhushoivassa (Kangasniemi \& Andersson 2011). Robotiikan käyttö voisi vapauttaa hoitajien työaikaa viidenneksen nykyistä enem- 
män suoraan asiakkaalle niihin asioihin, joita ei tekniikalla voida toteuttaa. Tekniikka kun ei koskaan voi korvata vastavuoroista toimintaa, aitoa kohtaamista hoitajan kanssa tai hänen kosketustaan.

Hoitajien toiminnan iso merkitys asiakkaan elämänlaadulle kirkastuu tulosten perusteella entisestäänkin. Palvelutapahtumien määrää tärkeämpää on kuitenkin se, mitä hyötyä asiakkaalle on palvelusta, millainen kokemus siitä hänelle syntyy ja miten se auttaa häntä pärjäämään. Työajan seuranta yhdessä asiak-

\section{Kirjallisuus}

Alexopoulos, G., Abrams, R., Young, R. \& Shamoian, C. (1988). Cornell Scale for Depression in Dementia. Biological Psychiatry, 23, 271284.

Arling, G. \& Williams, AR. (2003) Cognitive impairment and resource use of nursing home residents a structural equation model. Medical Care, 41(7), 802-812.

Arling, G., Kane, RL., Mueller, C. \& Lewis, T.(2007). Explaining direct care resource use of nursing home residents: findings from time studies in four states. Health Services Research, 42(2), 82746.

Buchan, J. (2005). A certain ratio? The policy implications on minimum staffing ratios in nursing. Journal of Health Service Research and Policy, 10(4), 239-244.

Cummins, R. (2005). Moving from the quality of life concept to a theory.Journal of Intellectual Disability Research, 49(10), 699-706.

Duffield C., Gardner G. \& Gatling-Paul C. (2008). Nursing work and the use of nursing time. Journal of Clinical Nursing, 17(24), 3269-3274.

ETENE (2008). Vanhuus ja hoidon etiikka. Valtakunnallisen terveydenhuollon eettisen neuvottelukunnan (ETENE) raportti. ETENE-julkaisuja 20, Vantaa.

Fahey, DF. \& Burbridge G. (2008). Application of Diffusion of Innovations Models in Hospital Knowledge Management Systems: Lessons to Be Learned in Complex Organizations. Hospital Topics, Spring, 86, 2, 21-31. kaan elämänlaadun arvioinnin kanssa tekee työn paremmin näkyväksi ja mahdollistaa vanhustyön kielteisten mielikuvien, toimintakulttuurin ja ajattelutapojen uudistamista. Se on askel kohti ikääntymispolitiikan ja vanhustyön korkeimpana tavoitteena olevaa iäkkäiden ihmisten hyvän elämänlaadun turvaamista myös hoivan saajana.

\section{Yhteydenotto:}

Riitta Räsänen, TtM, YTT

Asiantuntija, kouluttaja, Laatuhoiva $\mathrm{Oy}$

Sähköposti: riitta.rasanen@laatuhoiva.fi

Fahey, T., Montgomery, AA., Barnes, J. \& Protheroe, J. (2003). Quality of care for elderly residents in nursing homes and elderly people living at home: controlled observational study. $B M J$ 2003 Mar15;326(7389):580.

Hegney, A., Plank. A. \& Parker, V. (2003). Nursing workloads: the results of a study of Queensland Nurses. Journal Nursing Management. 2003 Sep;11(5):307-14.

Hentinen, M, Airaksinen, AR \& Vuorela, E. (1984). Hoitohenkilöstön rakenteen ja työnjaon muutoksen vaikutukset potilaan hoitoon ja hoitohenkilöstöön. Teoksessa: Kalkas H. \& Sinkkonen S. (toim.) Sairaanboidon vuosikirja XX1983-1984. Helsinki: Sairaanhoitajien koulutussäätiö.

Hänninen, T \& Pulliainen, V. (2001). Neuropsykologinen seulonta. Teoksessa Erkinjuntti, T. \& Rinne, J. \& Alhainen, K. \& Soininen, H (toim.) Muistihäiriöt ja dementia. Duodecim. Karisto. Hämeenlinna, 348-357.

Kane, RL, Flood, S, Keckhafer, G. \& Rocwood, T. (2001). How EverCare Nurse Practitioners Spend Their Time. Journal of the American Geriatrics Society 49:1530-1534.

Kangasniemi, M \& Andersson C. (2011). Enemmän inhimillistä hoivaa. Robottien avulla voitaisiin jo nyt tehdä viidennes sairaanhoitajien ja lähihoitajien töistä. Etla, Keskustelunaiheita nro 1237. www.eva.fi/wp-content/uploads/2016/09/Enemmän-inhimillistä-hoivaa.pdf. Luettu 11.2.2017.

Koskinen, S. \& Seppänen, M. (2013). Gerontologinen sosiaalityö. Teoksessa Heikkinen, E \& Jyrkä- 
mä, J. \& Rantanen, T (toim.) Gerontologia. Helsinki: Duodecim.

Laine, J. (2005). Laatua ja tuotannollista tehokkuutta?

Taloustieteellinen tutkimus vanhusten laitoshoidos$s a$. Stakes. Sosiaali- ja terveysalan tutkimus- ja kehittämiskeskus. Saarijärvi: Gummerus Kirjapaino $\mathrm{Oy}$.

Lawton, MP. (1991). A Multidimensional View of Quality of Life in Frail Elders. Teoksessa Birren, JE. \& Lubben, JE \& Rowe, J. \& Deutchman, D. (toim.) The Concept and Measurement of Quality of Life in the Frail Elderly. Academic Press. USA.

Liukkonen, P. (2008). Henkilöstön arvon mittaaminen. Helsinki: Talentum.

Morin, D. \& Leblanc, N. 2005: Less money, less care: how nurses in long-term care allocate hours of needed care in a context of chronic shortage. International Journal Nursing Practice, 11(5): 21420.

Nussbaum, M. (2011). Creating Capabilities. The Human Development approach. Cambridge: Harvard University Press.

Partanen, P, Heikkinen, T. \& Vehviläinen-Julkunen, K. (2005). Sairaanhoitajien työolobarometri 2004. Suomen sairaanhoitajaliitto ry:n jäsenkysely. Helsinki: Suomen sairaanhoitajaliitto.

Peltokorpi, P. (2007). Hoitohenkilöstön työajankäyttö ja henkilöstömitoitus vanhusten pitkäaikais-

hoidossa. Pro gradu -tutkielma. Kuopion yliopisto, Yhteiskuntatieteet.

Pieper, R, Heilbetz, C \& Frommelt, M. (2008). Quality Management and the Care Keys Quality Matrix.Teoksessa Vaarama, M,Pieper R \& Sixsmith Andrew (toim.) Care-related Quality of Life in Old Age. Concepts, models and empirical findings. New York: Springer.

Pirhonen, J. \& Pietilä, I. (2015). Patient, resident or person: recognition and the continuity of self in long-term care for older people. Journal of Aging Studies, 35, 95-103.

Pusa, A-K (2007). The Right Nurse in the Right Place. Nursing Productivity and Utilisation on the RAFAELA Patient Classification System in Nursing Management. Väitöskirja. Kuopion yliopiston julkaisuja E. Yhteiskuntatieteet 147.

Rauhala, A. (2008). The Validity and Feasibility of Measurement Tools for Human Resources Management in Nursing. Case of the RAFAELA System. Akateeminen väitöstyö. Kuopion yliopisto.

Ruontimo, T. (2012). Henkilöstömitoituksen hallittu tulevaisuus. Sosiaali- ja terveydenhuollon ammattihenkilöt lukujen takana. Sosiaali- ja terveysalanammattijärjestö Tehy. Julkaisusarja 2.

Räsänen, R. (2011).Ikääntyneiden asiakkaiden elämänlaatu ympärivuorokautisessa hoivassa sekä hoivan ja johtamisen laadun merkitys sille. Väitöstyö. Lapin yliopiston julkaisuja. Yhteiskuntatieteet.

Räsänen, R. (2014). Uhka vai mahdollisuus? Hyvällä omaisyhteistyöllä laatua vanhusten pitkäaikaishoidossa. Gerontologia 1.

Räsänen, R. (2015).Kiirettä pitää vai pidetäänkö kiirettä? Kiire vanhusten hoitotyötä värittämässä. Gerontologia 1/2015.

Räsänen, R. \& Leppälehto, S (2016). Ei mitä tahansa johtamista vaan gerontologista johtamista sen olla pitää. Gerontologia 1/2016.

Sainio, S., Koskinen S., Sihvonen A-P, Martelin, T. \& Aromaa, A. (2014). Teoksessa Noro, A. \& Alastalo, H. (toim.) Iäkkään väestön terveyden ja toimintakyvyn kehityslinjoja. Vanhuspalvelulain 980/2012 toimeenpanon seuranta. Tilanne ennen lain voimaantuloa vuonna 2013. Tampere: Terveyden ja hyvinvoinninlaitos, raportti 13.

Sand, H. (2003). Sateenkaaren päästä löytyy kultaa. Acta Universitatis Tamperensis nro 191. Tampereen yliopisto. Tampere.

Saranto, K., Ensio, A., Tanttu, K. \& Sonninen, A.L (2008). Hoitotietojen systemaattinen kirjaaminen. WSOY Oppimateriaalit Oy.

Sharkey, S., Hudak, S., Horn, S., James, B. \& Howes, J (2011). Frontline caregiver daily practices A comparison study of traditional nursing homes and The Green House project sites. Journal of the American Geriatrics Society, 59, 126-131.

Soini, H., Luoma, M-L, Muurinen, S. \& Varis, M. (2008). Muistisairaiden elämänlaadun mittaus. Havainnointi QUALID-mittaria käyttäen Helsingin vanhainkodeissa ja palvelutaloissa vuonna 2008. Helsingin kaupunki, sosiaalivirasto.

Spilsbury, K., Hewitt, C., Stirk, L. \& Bowman, C. (2011). The relationship between nurse staffing and quality of care in nursing homes: A systematic review. International Journal of Nursing Studies, 48, 732-750. UK.

Stenvall, J. \& Virtanen, P. (2012). Sosiaali- ja terveyspalvelujen uudistaminen. Kehittämisen mallit, toimintatavat ja periaatteet. Tallinna: Tietosanoma.

Tervo-Heikkinen T. (2008). Hoitotyön vaikuttavuus erikoissairaanhoidossa. Väitöskirja. Kuopion yliopiston julkaisuja E. Yhteiskuntatieteet 162.

Työturvallisuuslaki 23.8.2002/738. Luettu 14.4.2015. 
Vaarama, M. (2002). Tavoitteena vanhan ihmisen hyvä elämänlaatu. Teoksessa Voutilainen, P., Vaarama, M., Backman, K., Paasivaara, L., Eloniemi-Sulkava, U. \& Finne-Soveri, H. (toim.): Ikäihmisten hyvä hoito ja palvelu. Stakes. Oppaita 49. Saarijärvi: Gummerus Kirjapaino Oy, 11-18.

Vaarama, M. \& Ylönen, L. (2006). Kotihoidon laatu ja tuloksellisuus Espoossa. Asiakkaiden näkökulma. Sosiaali- ja terveystoimen julkaisuja 3. Espoo, 13 .

Vaarama, M., Pieper, R \& Sixsmith, A. (2008). The General Framework and Methods of the Care Keys Research. In Vaarama, M., Pieper R. \& Sixsmith Andrew (eds.): Care-related Quality of Life in Old Age. Concepts, models and empirical findings. New York: Springer.

Vaarama, M. \& Ollila, K. (2008). Koettu hyvinvointi ja elämänlaatu kolmannessa iässä. Teoksessa: Moisio, P., Karvonen, S., Simpura, J. \& Heikkilä, M (toim.): Suomalaisten hyvinvointi 2008. Stakes. Helsinki,17.
Vaarama M., Siljander E. \& Luoma M-L (2010). Suomalaisten kokema elämänlaatu nuoruudesta vanhuuteen. Teoksessa: Vaarama, M., Moisio, P. \& Karvonen, P. (toim.) 2010: Suomalaisten byvinvointi 2010. Yliopistopaino, Helsinki, 133.

Vaarama, M. \& Karvonen, S. \& Kestilä, L. \& Moisio, P. \& Muuri, A. (toim.) (2014). Suomalaisten byvinvointi 2014.

Laki ikääntyneen väestön toimintakyvyn tukemisesta sekä iäkkäiden sosiaali- ja terveyspalveluista Vanhuspalvelulaki. 28.12.2012/980. Finlex.

WHOQOL-group (1996). WHOQOLBREF- Introduction, administration, scoring and generic version of assessment. The World Health Organization. Geneva.

Vento, S. (2014). Asiakasläbtöisyys ja tuottavuus hoivapalveluissa. Laurea Julkaisut I 41.

Weiner, MF, Martin-Cook, K., Svetlik, DA, Saine, K., Foster, B. \& Fontaine, C. (2000). The Quality of life in late-stage dementia (QUALID) scale. Journal of the American Medical Directors Association, 1(3), 114-116. 